されなかつた。しかし今までの計算によつてボタのガ ス化は $1,000 \mathrm{kcal} / \mathrm{Nm}^{3}$ の非常に廉価な貧がスができ てニークス炉の加熱用に使用される。」

その上ガスは本質的に他の目的たとえば缶の抈熱用
にも用いられ経済的利益をもたらす。この方法の重要 なのは他の方法では活用できない燃料の熱を利用でき るという点で新しい技術的かつ経済的な可能性を与え るものである。

\title{
Gasification of Low Grade Fuels (Washery Wastes)
}

\author{
by G. Lorenzen
}

(Dr. C. Otto \& Comp. G. m. b. H.)

SYNOPSIS :- In large scale trials in an Otto cross-flow oven (10t/d), Dr. Leithe and his co-workers got a cheap, weak gas $\left(800 \sim 1,200 \mathrm{kcal} / \mathrm{Nm}^{3}\right)$ from washery wastes, efficiency being $55 \sim 65 \%$.

U.D.C. $662.6 / .8: 64$

\section{家庭燃料対策について}

一一眧和 29 年 1 月 2 日受理一一

\section{嘉納·吉彥}

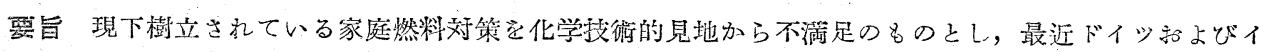
ギリスで発達してきた低犋炭を利用する家庭用無煙固体然料の生蓙技術と，てて数年来わが国で研究さ

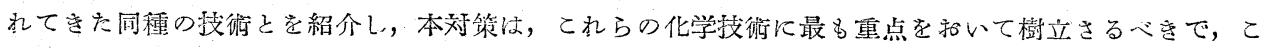
れを実現するにはすず機權的と钼念的に改善したい問題のあることを指摘した。

\section{I 序言}

家庭燃料間題:さ森林資源の保存，国民生活の経済上 心う切実な問題之関聯し，政府も国民も，亡もに大き な関心を寄せて解決に当るべきであるにもかかわらず， その施策に，その世論に，いまだ真劍味の欠けている ことは遺憾である。

政治の貧困は，これを一言にしていえば，国民大衆 の貧困を心から憂うる心構えの足らぬことにつきる。 周知のごとく家庭燃料の大宗である澵炭の価格仗逐年 高騰し，施策の効果はほとんど期待できない。薪炭を 燃料之する古来の風習は，文化低き時代の単なる蹈醲

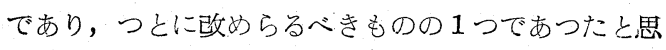
う。筆者はこの見地に立ち，戦後ただちに薪炭代替燃 料の製造法につにて調查を進め, 爾来, 真劍にこの問 題々取組み，研究を重ねてきた者で，ここに，その概 要と所見をのべてみたいと思う。

\section{II 森林資源の荒廃と薪孷価格の高鵱}

わ汸国の森林資源は昭和25年森林資源綜合対策協議 会の調查によると，利用可能林約 33 億石，その年成長
量的 9,000 万石，これに対し年間伐採量は約 2 億石， その過伐量は実に 1 億 1,000 万石に達している。この 年間伐採量約 2 億石のうち，薪宸材は薪材約 5,000 万 石, 木炭材約 5,000 万石, 計約 1 億不であるから毎年 総伐採量の半分を煙りにしていることになる。 森林の過伐濫伐の傾向を生じてきたのは昭和 4,5 年 のころからで，それ以来，昭和28年までの過伐量は累 計約56億石に達し, これが豪雨の度に, 耕地を流し, 人家は倒れ，人命さえ吞む大きな原因之なつている。 現在, 伐採の行われている開発林は約25億石であるか ら，かりに今後も每年 2 億石づつ伐採してゅくとすれ ば，成長量の約 2.5 倍となり，あと $12 ， 3$ 年で完全に伐 りつくすことになると憂えられている。

治山治水は古代にあつては政治の全体であつたが， 戦後, 繰り返す河川の汇濫による災害の激冠さをみる につけても，政治は速かに山に水に復らねばならぬこ とがわかる。森林資源のかくのごとき荒廃は，ひいて 薪炭価格の高騰となり, 今冬の小売価格をみると, お よそつぎのごとくで，ここ2，3年のうちにほとんど倍 
近くの值上りを赤している。

$$
\text { 木炭 ( } 4 \text { 貫俵) }
$$

薪 (一把)

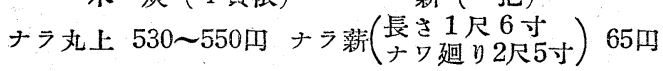

ナラ丸並 $490 \sim 510$ 雜木薪

60

䧴丈上 $\quad 460 \sim 470$ 泳材㵏 55

雜丸並 $450 \sim 460$ マッ薪 55

このような薪崖価格の高騰が国民大衆の生活をいか に驾 しつつあるかにつき，議政壇上に抢いて婦人代 議士すらも論議していないのはどうしたものであろう か。産米の減収は外米の輸入によつて臨機の処置が、と れるが，薪炭にはこの切札がなく，国民は全く自然の 成り行きに委すほかない現状である。

\section{III 槊林瓷源対策と家庭然料白書}

新聞紙上に伝えられたこれらの対策, 白書, 勧告な どを通覽すると，昭和27年に林野庁は森林資源の保護 育成を目的とした改正森林法を発布し，これによつて 樹木の年間生長量に見合うだけの伐採制限を行つてい るが，これは適正伐期齢（樹齢の意味で,杉36〜60年， 檜 41 60年，松31〜 50年など）以下の若木にのみ適用 されているものである。昭和28年には総理府資源調査 会抢よび林野庁から家庭然料合理化に関する勧告とか 家庭然料白書污発表され，これらの施策としては，奧 地林の開発, 造植林の推進, 輸大促進による供給増加, 木材使用の合理化による消費節約, 改良カマドの使用 奨励による薪炭消費の改善, 穴明煉炭, 豆炭の増革お よび石油コンロの普及などがあげられている。

これらの施策は无もであるが，これを化学技術的に 検討してみると，消極的なもので，もつと高度の化学 技術を織り込んで立案さるべきではないかと思う。換 言すれば最近の進歩に照して地下資源の有効活用を積 極的に行うようにされたいのである。地下燃料資源は もちろん石油と石炭であるが，石油需要量の 9 割を輸 入するわが国での石油コンロの奖励（昭和28年度中に 90万台とする) は応急対策以外の何物でもない。今冬 の石油異変をみてもわかるとおり，輸入外油の変動に 直ちに左右され，国民は安心してこれに依存すること ができない。豆炭は昭和 27 年度の生産実積 85 万 $\mathrm{t}$, 昭 和 28 年度 110 万 $\mathrm{t}$ の計画であつたが，積極的な奖励は 行われていないとのことである。現在市販の穴明煉岸

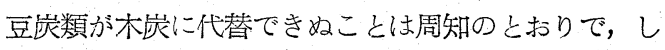
かも，その洒格は豆炭（15個大り）270２80円，穴明 煉炭（高さ 4 寸14個大り）260２70円で，けつして低 廉とは心学ない。これは督困な化学技術のしからしむ るもので，ここに家庭然料間題解決の鍵があり，よき 代替燃料の研究生産こそ戦後直ちに奨励実施さるべき
ではなかつたかと思う。

\section{IV 家庭燃料原料としての石炭}

わが国の石㞸は採掘可能量90億 $\mathrm{t}$ といわれ，毎年 5,000 万 $\mathrm{t}$ づつ採掘しても前途に不安は感じないが, 出炭量の約 6 割は粉炭で，しかも，低質炭と称せられ るものがそのかなりの部分を占めている。最近, 高炭 価問題が特にやかましく，日本経済の癌とまでいわれ， これがために通商産業当局の孷価引下げ対策も新聞紙 上に伝えられているが，筆者のみるところでは，採炭 能率の增進, 選㞸設備の近代化など, もちろん結構で あるが，同時に低質粉炭処理対策をもつと真剣にとり 上げるべきではないかと思う。

石炭を生のままで使うなとは古くから欧米燃料界の 金科玉條で，これに従つて加工法はよく発達し，今日 なほ停止するところがない。これらの技術のうち，炭 础で簡単にできるものは，不況時切抜け対策ないしは

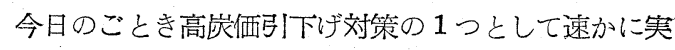
行に移されたらどうであろうか。さしづめ低質粉炭を 原料とする家庭然料製造のごときはまさに一石二鳥と もいうべきものではなからうか。前述の総理府資源調 查会の勧告によると, わが国の家庭燃料消費量は, こ

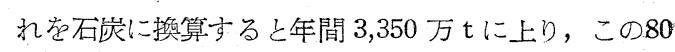
\%は薪炭であるとのことである。しからば，わが国の 粉炭産出量は，ほほ家庭で消費される薪炭総量に匹散 しているということができる。石㟶業者には石炭に対 する強い愛着がある筈である。折角苦労して掘り出し た石炭か，スン物として值を吒かれ，山から出て行く 姿をみて無関心ではおられまい。これを山元で加工し， 化精して華々しく送り出してやる位の親心誰しも懷 いて抢られる思う。

\section{$\mathrm{V}$ 欧米の家庭燃料工業概観}

ドイッでは古くから褐崖砎附近に㷄炭工場を設け， その製品を專ら家庭用に向けている。資料は少し古い が，1934年ごろには年間 3,100 万 $\mathrm{t}$ も生産されてい た。この煉炭は水分 $60 \%$ 程度の褐炭（わが国の亜炭に 相当）を $5 \mathrm{~mm}$ 以下に粉碎し：シュルッ(Schulz) 式円 筒多管乾燥機で蒸汽を用いて乾燥し，水分を14〜15\% としたのち粘結剤を加えずに $1,200 \mathrm{~kg} / \mathrm{cm}^{2}$ の高圧で圧 㩁して製造するものである。この場合の原料褐炭とし てはモンタンワックス(Montanwax) 含有量の多い, 成型し易いものを用いたが，その後モンタンワックス の少ないものもアップェルベック(Apfelbeck)式高圧 熯炭機で $1,500 〜 2,000 \mathrm{~kg} / \mathrm{cm}^{2} に$ 圧撨して製造している。 戦前のドイッは低温乾溜工業がよ発達し, これか ら得られる低温タールを人造石油の製造に, 副産粉 
ーライトはこれにピ，チを混せててーライト煉炭と して家庭用ないしは汽缶用に供していたか，最近にい たりピ，チを粘結剤々した石炭豆梀炭のルルギ（Lurgi）式低温乾溜工業》か発達してきた。この乾溜は, クルミ大の磨青炭を乾溜するのに用いられたルルギ式 绕條がス低温乾溜装置をとのまま使用するものてある か，歴青炭の種類により粘結剤を用いるか，あるいは 用いないて煉崖化される。

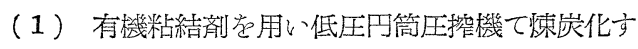
るもの

これは瀝青炭を0〜2mmに粉碎して乾燥方る。これ にピ，チ1〜2\%，西硫酸パルプ廃液(50\%脱 水) $5 \sim 7$ \%を加光よく混合揘和し，約 $500 \mathrm{~kg} / \mathrm{cm}^{2}$ の圧力て卵型 煉孷とし，でル下式乾燥機て附着水分を除いて固化せ しめて乾溜するものてある。

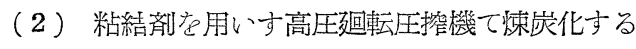
छの

歷青炭を0〜 1mmに粉碎して乾燥する。原料炎の種 類により完全に粘結剤なしかまたは有機粘結肪を混せ て高圧廻転圧䇽機て梀炭化する。この場合の圧搾圧力 は 1,500 2, $000 \mathrm{~kg} / \mathrm{cm}^{2}$, 圧䇽温度は $50 \sim 250^{\circ} \mathrm{C}$ であ る。この㑛炭はそのまま乾溜されるが，その際はてき るたけ急儌に $350 \sim 400^{\circ} \mathrm{C}$ まて加熱し，その後は希望 する製品の揮発分（火着と関係少る）に応し引続い て 500 $800^{\circ} \mathrm{C}$ まてさらに加熱するものである。

ルルキ式低温乾溜装置はわか国ても人造石油事業に 採用していたから詳迈の必要はないか，要するに酸素 苍除いた烍條がス(Spulgas)という乾溜ガスと燃焼が スとの混合ガスて内熱的に加熱される直立炬てある。 この炉は予熱層, 乾溜層, 冷却層の 3 層からなり, 石 炎は最上部の予熱層で約 $150^{\circ} \mathrm{C} に$ 加熱されて中部の乾 溜層に大り，ここて $600 〜 850^{\circ} \mathrm{C} に$ 加熱された洗㹣が スて乾溜されたのち，下部の泠却層に大り，冷がスに よつて 100〜 $200^{\circ} \mathrm{C}$ に冷却されて最下部の電気的に作 動される取出穖によつて排出されるものである。

本炉には小型と大型とがありまた別に鉄壁を隔て て間接に加熱する方式のものもあり，両式とも大規模 に結果よく操業されているとのことてある。

イギリス扑よひフランスても古くから研究され1935 年に欧米を視察された東大教授佐野考之助氏に上れ は，不粘結性石炭またはとのコーライトを用いたピ， チ煉炭の低温乾溜事業を数カ所てみられたとのことて ある。

最近イギリスのDan T. Phillips氏 2)は無煙家庭燃 料の製造技術と生産対策について論逨し, 理想的の無
煙家庭然料はガスであるが，無煙固体然料に対する一 般家庭の要求も強いから，カ次事業者はガスだけを家 庭に供給与れはよいという従来の考えかたを変え，家 庭て使える無煙固体燃料老も同時に生産するようにし て，その要求に応すへきてあるとし，イギリスて多量 に産出される妈粘結性汽缶用炭（水分1.2 1 1 \% , 灰 分 4 0 5.0\%，揮発分10.0 120\%）から，ます卵型ピ ，樕炭をつくり，これを乾溜して所要の製品とする ことを研究し，その笑施を提唱している。

氏の調査研究に上ると，家匡用無煙固体然料它目的 とする畉型ピ，チ楝炭の乾溜は，ここ25年来各国て行 われたか，成功しているのはつきの人々抢よひ会社で あるとのことである。(1) H. M. Fuel Research Staff (2) Dr. Paul Dvorkovitz (3) Dr. S. Roy Illingworth (4) The Suncole Process ( 5 ) Humphrey \& Glasgow, Ltd. (6) Powell Duffryn Associated Collieries, Ltd. (7) The Disticoke Company, Paris (8) Sutcliffe Speakman, Ltd.

粉粉(Duff)から理想的の無煙燥炭を製造する工程は

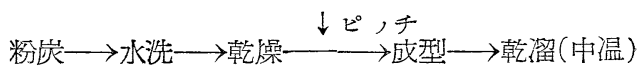
という簡単なものてあるが，完全なもの定高収率て得 るには普通のピソチ豆梀崖製造の時よりもつきの諸点 に注意しなけれはなら好とのへている。

(1) $60 x, シ ュ$ (B.S.S.)以下の微粉党除くこと

（2）粉炭の乾燥は圧力 $251 \mathrm{~b} / \mathrm{in}^{2}$, 温度 $400 \sim 700^{\circ} \mathrm{F}$ (205 370 $\left.{ }^{\circ} \mathrm{C}\right)$ の過熱蒸気在直接に噴射して行 うこと

（3）石炭粉末とピ，チとの混合，捏和を一層丁寧に すること

（4）ピ，チは軟化点 $75 \sim 78^{\circ} \mathrm{C}$ (Ring and Ball Test), 遊離孷素12〜15\%程度のものとし，その混 大量を 6〜10\%とすること

（5）成型圧力を約 $2 \mathrm{t} / \mathrm{in}{ }^{2}\left(\right.$ 約 $\left.300 \mathrm{~kg} / \mathrm{cm}^{2}\right)$ とすること， また卵型と゚，チ煉炭を乾溜する利点をつきのことく のベている。

（1）乾溜煉炭は無煙て，残留挥発分をえの用途によ り任意に調節できること

（2）強度け残留揮発分を $6 \%$ 以上にしなけれは原料 梀炭の約 6 倍に増加てきること

（3）容積密度さっクルミ大の最良無煙炭とほほ同しで ある

（4）火床試験によれは着火性に難色なく長時間高い 火力を維持する 
（5）需要者は $97 \%$ 以上の均一製品を入手できる

（6）輸送中の破損率はきわめて少なく $2 \%$ 以下であ る

（7）燃焼初期の火力はきわめて強いが，あとになる と表面が細かい灰に覆われ火力が減つてくる

ピッチ練炭の乾溜方法につにていイギリスおよび特 にフランスでよく研究され企鄴化されたが，多くは技 術上の欠陥とか資金難のために休止された。これらの 方法を大別すると

（1）レトルトと炉を用い外熱的に乾溜するもの

（2）直立レトルト学用い内熱的に乾溜与るもの となり，熱効率はもちろん内熱式が優れているが，こ の式で大規模に策際に成功しているのは多数の媵小屴 察から成る乾溜师だけであるとのことである。

最後に氏はイギリスでは現在家庭用燃料がスとして 髎炭炬がス(Coke Oven Gas) の使用を奨版する政策 をとつているので, 石崖ガス炉から副産されるがスコ ークスは非常に減少し，近い将来にはガス事業者によ る嘼炭炉がスの製造が盛んになり一層減座されるもの 々みている。また現在イギリスでは約 900 万世带がが ス使用している方，各世带! 中固体燃料を使う設備古 少なくとも 1 個はもつているので，今後のガス工業は 弱粘結性乾燥汽缶用㟶加らがス之同時に無煙固体然料

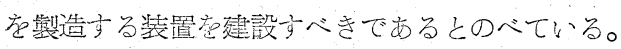

アメリカは地上，地下両資源に惠まれているので家 庭燃料としては蘶, 天然がス, パイロファックス (Pyrofax)，不油，無煙炭など䇺富であるが，西部之 西南部では良質褐崖を多量に産出するので，その利用 についても古くから研究実施されて抢り，これを大別 するとつぎのごとくなる。

（1）ドィツの褐炭煉炭法に従うもの（2）粘結郕色

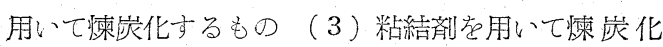
乙低温乾溜するもの（4) 乾溜崖とし粘結剂尼用い て煉炭化するもの（5）蒔油で加熱処理し低温乾溜 玄るもの

ドイッの褐炭煉炭法に従うものは1922年ごろドイッ から機諓党購入して試みたが，アメリカ産の褐炭はさ ンタンワックス含有量が $1.5 \%$ (ドイッのものは13〜 $25 \%$ にすぎないので結果が思わしくなく，直ちに採 用できぬという結諭を出したうっ。粘結郕を用いた卵型 褐炭煉炭の低温乾溜では S. M. Darling 氏の研究し たDarling Retort ‘)が興味深い。このレトルトは傾 斜した鉄管の一群を外熱主るもので，その特徴注灯内 にある鉄管と同長の鉄管を，同一傾斜 $\left(34^{\circ}\right)$ 老もつて 外側に取付け，この部分で乾溜煉炭を冷却し，半連続
的に乾溜するところにあるようである。

褐炭を軽油で加蓺処理したのち低温乾溜亦るもの は，1939年ごろE.P. Schoch氏 5) が研究し，褐炭な 軧油中で $230^{\circ} \mathrm{C} に$ 加熱して約 $20 \%$ の油分を含むものと し，(同時に脱水される)これを $550^{\circ} \mathrm{C} て ゙$ 乾溜して発熱 量 1,2 万B.T.U. $/ 1 \mathrm{D}(6,660 \mathrm{cal} / \mathrm{kg})$ の塊状乾溜宸を 46

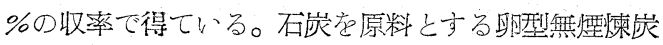
の製造法はH. Smith氏が矿究しSmith Process(また は. Carbo-Coal Process) ${ }^{6}$ として有名である。この方 法はまず石炭をカーボランダム製水平レトルト中で連 続的に低温乾溜してコーライト蕰製造し，ついでこれ

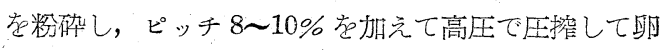
型煉炭とし, 傾斜窐鴜式がス炬で高温乾溜するもので ある。

以上を要玄るに低質粉炭を原料々方る家庭用無湮固 体燃料の製造については戦後ドイッ抢よびイギリスで 特に発達しつつあるようである。そして，无れらの技 術をわが国在来の加工炭技術々比較方る時，いかに国 情のしからしむるところと虬立まりにも隔りのあ るのに驚かざる教得ない。

\section{VI・クが国の家庭燃料に関する研究}

わが国でも家庭燃料堂地下資源（业宸，石炭）に求 めんと方名研究估古くから行われ，これに関する特許 も沢山劣るが，原料としては亜炭学用いたものが多く， 技術的には一般に牥稚で，大量生産に適するものはほ とんど見当らない。亞崖の熫出量は大正初期から約 30 年間は年10万 $\mathrm{t}$ 台にすぎなかつたが，支䣂事变未期か ら急增し，一挙に200万 $\mathrm{t}$ 台にも上つたこともある。 しかし，出炭量は多数の小企業の累計で，常に石炭の 誌況によつて左右され，その品質も交献なぼに示され たものより滛かに劣る場合が多く，加，均一性を欠 いているので木炭に代替できる良質加工炭を大規模に 製造する場合の対象としては考えられない。

西炭の加工法中，近年に至り目立つてきたのはドィ ツ褐炭煉宸法の技術に従つたものである。わが国で本 法に最初に注目したのは元の南渵州鉄道株式会社で, 確か眧和10年ごろ阿部良之助氏がアップエルベック式

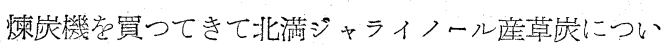
て研究し成功されたように聞いている。この方法はド イツ褐炭のごとく崖層の厚さ平均 $27 \mathrm{~m}$, 最大 $300 \mathrm{~m}$ も あつて常に均一な性状のものが得られ，かつモンタン ワックスを多量に含有しているものには安心して兴施 できるきのと思われるが，前述のごとくアメリカで成 功していないこと，わが国の亜炭が概数薄層で均一性 を欠き，比徬的多量に産出する炭質亚㟶は灭分が多く， 
これから良質加工炭か得られるとは考元られ妨こと， およひ超高圧圧㩁機としてドイッのものに擬したもの を使用する場合に，その寿命か工業的に問題てあるこ となとの縣念かあるものてある。しかし，本法をわか 国の亜炭, 嶉炭, 低度歷青炭なとに適用して成功すれ は，わか家庭燃料界への一つの福音てあるなら，その 研究, 企業枝援され促進されるへきもの之思う。

わか国て市販される穴明莱炭, 豆炭類の多くは, そ の原料として低質コーライト粉（多く小炭砝て行われ ていそ壹焼という原始的乾溜法による粗製品), コーク スブリーズ (製鉄所，ガス会社の製品屑），西炭などを 安く買い粘土フフフリなと童加えて成型したものて， まれに木炭粉を加えて火着をよくしたものもあるた木 炭には到底代替てき好ものてある。またこれを多少改 良せんとしたものが然料研究所（現資源技術訌験所） て研究された堌熱亚炭と称せられるものて，これは业 炭をタールて者て脱水と同時に油を浸透させたものて ある。な抢，これを乾留したものもあるか捕販されて いないようてある。

笔者は上过のことき, わか家庭燃䊀界不振の実状に 鑑み, ここ数年来, 研究它重补犬結果, 褐崖, 低度歷 青炭を原料とする膨閏炭㷧炭乾留法了わ的国狺に適し たものてあるとの結論を得た。本法は既に特許てとな り，昭和26年 4 月には燃料協会てのへ，また必要の向 には研究報告8)も配布してむるのて，ここには要点の みを㭊へてみる。

膨閏炭とは石炎扮末に高温タールあるいはとの重質 溜分(クレォンート油,アンスラセン抽)存加元約 $350^{\circ} \mathrm{C}$ の下に $6 \sim 8 \mathrm{hr}$ 加熱して製造されるピ，チ状のもの て，その性状!灰分のやや多いピ，チと思えは差支え ない。

膨閏炭の研究はわか国の粘結炭缝出量放乏しいため に, 多量に産出される不またに妈粘結炭の粘結力増大 の目的をもつて新村唯冶氏か燃料研究所て最初に研究 し，治金コークス製造上に貢献されたものて，そのの ち多くの研究者によつて研究9)され，その製造挍術は すてに砤五し，1950年の第 4 回呭界動力会議（ロンド ン）にも報告10)されている。この膨閏崖を徚炭の粘結 郕として便用する研究もつとに然料研究所て行わ机特 許となつているか，これはわか国のピ，千生産量が しいためて，昭和 28 年度には約 20 万に達したか，需 要も増加し鉄道用ピ，チ煉炭の製造にも依然不足勝の 有栚てある。ピ，チは将来軽金属工業か復活すると電 極用炭素の製造原料となるものてあるから石宸乾溜工 業かよ㳊と発撻しないかきり, 欧米のことくピ， 栾
炭の乾溜によつて大量の家庭用無煙固体燃料を製造す ることは望み難い。故にわか国てはつきのことき製造 工程によることか考えられる。

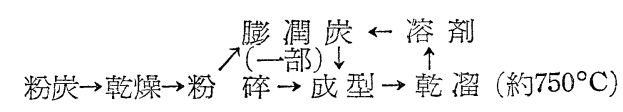

膨潤炭梀炭乾溜法の基礎研究は炤和 23 年加ら約 2 年 間燃料研究所の新村唯冶氏，点場有政氏，森田久三氏 らの蓺心な協力を得て行われたものて，ます低質粉炭 を乾燥して水分を約 $5 \%$ 以上ししたのら微粉とし，節 分して10〜60メ，シュのもの变惊炭原料，60メ，シュ 以下の節下を膨閏炭原料とする。膨閏㞸は重質クレオ ソート油を溶剤として製造し，乞の融点夻 $80^{\circ} \mathrm{C}$ 内外 に調節し，これを10〜12\%（原料㟶によつて:さ15\%) 使用して卵型凁炭とする。この際の混合, 担和は丁宾 に行い，つきの成型も普通梀炭の場合上りやや高圧 (約 $300 \mathrm{~kg} / \mathrm{cm}^{2}$ ) 岂用いる。乾留温度は普通 $700 \sim 750^{\circ} \mathrm{C}$ にするか，これは $7 \mathrm{C} 0^{\circ} \mathrm{C}$ 以下ては生成する溶剂の膨閏 能力か劣り, 溶剤を循環使用して一貫作鄴に上り大量 生産の目的を楒すことかてきぬことと, 製品の硬さ, 火着の工合和笑用上適当となるからてある。この研究 はついてダヴィ，ドンン (Davidson) 式低温乾留炉 （レトルト1基建設）と稼動的の水平式ガス炉厄用い て半工峃的に笑験され，つきのことき満足すへき結果 を得た。

原料孷 (北海;道天北裼炭)

水分 $131 \%$ 灰分 $10.15 \%$ 掩発分 38 12\% 固定炭素 $3862 \%$ 全硫黄 $045 \%$ 発蓺量 $5,190 \mathrm{cal} / \mathrm{kg}$

㱔品 (莭型無煙徚炭)

水分 $4.86 \%$ 灰分 $17.87 \%$ 揮発分 11 . $60 \%$ 固定炭素 $6567 \%$ 全硫黄 $0.45 \%$ 発熱量 $6,150 \mathrm{cal} \mathrm{kg}$

強度 $86.3 \%$ ( $80 \%$ 以上合格)

燃焼訌験（家庭然料試験法による）

合計点数 208 点 (太炭182点, 市販最良加工炭 111 点) 残灭率約 $11 \%$ (市販最良加工炭 約 $30 \%$ )

無煙, 無臭

本試䀦中，本品の特記すへき性状として，灰か木炭 と同様につきつきに表面から落ち，内部まて完全に 燃えつくすこと，およひ火持の特に長い（木炭の約 2 倍)ことか認められた。

家庭用無煙固体燃料の具備すへさ性質京, 欧米々わ か国とては生活の㥞式を異にするのて必すしも同一て ない。すなわち欧米の無昰梀炭より誃少強度を下けて も火着をよくする必要们方。発熱量は $6,000 \mathrm{cal} / \mathrm{kg}$ もあれは充分過き，笑用の結果ては $5, \mathrm{CoO} \mathrm{cal} / \mathrm{kg}$ 位で 
过差支えない。現在本法による無煙梀炭工場の建設費 は月産500 $\mathrm{t}$ 規模のものて約 4,000万円々推定され，そ の製造原価も割合に安く，小売価格を規在の市販加工 炭と同程度としても採算はとれるものとみている。

つきに本品の市場性につ、て㲘念される向もある が,前速のことく欧米の家庭にはよく普及されており， これを日本式に少しく改良すれは何ら心配のないもの と思う。本研究はその後に発表された前記 Dan T. Phillips氏の研究と較へてみると, その Key Points かあまりにもよく似て抢り，有力な技術的ならひに対 策的の裏付を得たものということかてきる。

\section{VII 家庭然料対策所見}

家庭燃料対策は現下一日も忽せにてきぬ重要対策の 1つてあり，あらゆる技術を綜合結集して確立せられ るへきものてあると思うか，現下樹立されているこの 対策をみると，欧米ならひにわか国てのこれに関する 最近の化学技術的進歩か充分に織り込まれているとは 思われる。

然料の本質か化学てある以上, 対策の中心を化学技 術におかなけれはならぬことは自明の理てある。筆者 の，ここ数年来の経験によると家庭燃翷対策を確立す るにはつきのこょき㙨構的ならひに観念的問題から改 善される必要加あるように思う。

（1）家庭用無䃌固体燃料を地下資源加ら生産する 場合, 原料は通商産業省 (資䝠庁), 製品は農林省 (林 野庁) の所管に属し, 企業を奖励し, 対策を推進する 中心か明確てない。周知のことくわか国の産業経盛界 はきわめて梁刻て所轄庁の強力な支援を得ても新規事 業の実現は容易てなく，ことに家庭燃料事業のことき は，従来の小資本による劣質加工炭の製造加たたり， 金融界て真面目に取扱われす，ます自己資金て生座さ せよけれは融資するという態度てあり，両者相俟つて ますます企業を困難ならしめている。そこて箓者はま す第 1 に, 家庭燃粼(菜炭, 加工炭)を地上資源による ものと，地下資佰によるものとに区別し，前者は従来 と扣り農林省, 後者は通商産業省の所管こすることを あえて提唱するものて西る。農林省には薪孷の専門家 は抢られるか, 在来のことき幼稚な加工炭技術は別と し，最近の進歩した製造掕術に対し，適正な判断を承 めることは少しく無理てはないかと思う。第 2 は本事 業のことき森林資㿟の保存, 国民生活の経済, 高炭価 引下けの諸対策之密接不可分の関係にあるもの!は，民 閒の自発的事業としてその成果を待つかことき態度に てす,むしろ最初の 1 単位工場位は官設民営とするか, あるいは大手筋崖吰を從恿して速かに実現させるよう
施策せらるへきものてはないかと思う。

（2）わか石炭業界の化学技術に対寸る認識理解 は欧米に輘へ一般に乏しいようてあるからここの技術 陣を強化しまつ之積極的に化学技術の応用による炭矿 の合理的経営に努力されることか切望される。

（3）ガス事業家の家庭用無煙固体然料生産への協 カもまた強く要望される。前記 Dan T. Phillips 氏 の意見をまつまてもなく筆者は国にガスと家庭用無煙 梀炭の同時生産を主張してきたか反響はは少しもなかつ た。ガス用宸の少ないわか国ては膨閏炭煉孷こそこれ に代るよい原料てはないかと思う。

（4）家庭然料への石油製品の使用采励は策を得た ものてはない。これは家庭燃料工業の発達を阻害する というような女々しい理由によるものてない。筆者は 20年以上も夜体燃料の研究に従事し, 終始その合理的 使用を工夫し主張11してきたたけに，液体燃紏使用の 根本観念から強く反対したい。石伷産出量の乏しい欧 州諸国て，家庭然然料として石妯の使用を奖㔙してい る国かあるてあろうか，筆者は寡聞にってこれを知ら ない。

\section{交献}

1) Lurgi Gesellschaft fur Warmetechnık M B. H., Schwelung von Steinkohle

2) Dan T. Phillıps, Gas World, 13, Jan. (1951).

3) O D Hood, Chem Met. Eng., 28, Jan., 10, (1923).

4 ) Stillman, Birquettrng, 237

5) E P. Schoch, Ind. Eng. Ohem, 31,1489 96 (1939).

6 ) 栗原爁司, 石炭乾留工業 833頁.

7 ) 特許第192043号, 同第197679号.

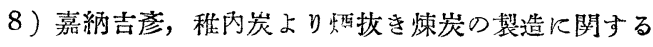
研究灾験郝告, 昭 24 年 6 月

嘉弰吉彥, 稚内炭人り化成木炭の㱔造研究, 昭 25 年10月

嘉柄吉彥，カス会社の水本式レトルトによる化成 木炭の製造研究概報, 昭25年11月.

9 ）燃協詰，昭24年11,12月，特許第182708号

10) A. Baba, “Indwstıal Developeent of Solvent

Treatment of Coal in Japan April 1950.

11) 嘉納吉彥, 航空発動機之燃料, 三菱石油研究資料, 第 2 卷第 4 号, 第 3 空第 1 号.

嘉納吉产, 今後の航空燃料対策について, 燃協沇, 
炤28年 5 月.

\title{
On the Domestic Fuel Policy
}

\author{
by Yoshihiko Kanō
}

SYNOPSIS:-The writer is not satisfied with the present policy of domestic fuels in Japan from the view point of chemical techniques and refers to:

1. the production techniques of smokeless domestic solid fuels which have been developed recently in Germany and in England using low quality coal.

2. the techniques which have been studied on the same problem as above in this country for these several years.

3. the importance of establishing a sound domestic fuel policy on the foundation of these chemical techniques. Finally he concludes that are some problems to be studied systematically and ideologically.

U.D.C. 622.41

\section{炭磺のガス誘導について}

一昭㕲 29 年 1 月 23 日新春特別講演会——

\section{北海道岸矿汽船株式会社 取締役 保安部長 境 田 三 郎}

要旨 ガス誘導（ガス拔き）は，1943年以来ドイッ，フランス，ベルキー，イギリスなどで急速に発澾 し，北海道でも試行されている。筆者らの炭砸調查団か一昨年行つた上記各国での調查にもとづきそ の技術の大要を述へる。まずガス誘導法に適当な諸條件を說明し，ついて本法の具体的内容を実例によ つて說明した。誘導したガスの利用法，ガス誘導の適用によつて得られた諸外国ての实際利益，わが国 と和ける現状と見涌しを述へる。

\section{I 緒 言}

戦後炭破における採宸並びに保安技術に種々進歩か もたらされたが，その中でガス誘導法は最も大なるも のの 1 つである。宸砸のガス誘導（ガス抜き， Gas Drainage）とは宸層または地層中に包蔵されている メタンガス，または払跡などに集積しているガスを高 濃度のままに鉃管に集め，坑内気流中に混することな し!坑外まで導く方法をいう。

設備の都合で坑外まで導かず坑内の安全な場所に放 出する場合もある。坑内に打いて石炭の採掘に伴い， メタンガスが発生する。これが恐るべき坑内爆発その 他災害の原因となるので，常に扇風機により大量の空 気を坑内に送り爆発に対して危険なく，また人蓄の衛 生に対しても安全な程度に稀繹して坑外に排出してい る。しかるに坑内梁度の大となつた坑内ではガスの発 生量か次第に多くなり，これを規定のガス量以下に薄
めるにはきわめて大きい扇風機と断面の大きい風道と を要するか，かかる坑内は通気坑道か長大となり，か つ激しい地圧のため必要な坑道断面積を維持すること か困難で通気抵抗は大となり, 強大な扇風機を運転し ても所要の風量をとおすことは困難となつてきた。 かかる状態で生産は制限され，新区域への進展も不 可能な炭砇が各所に生じ，各国ともこの打開に頭を悩 まし, 鋭意研究の結果, 西独の Forstmann, Schulz 両氏は坑内で地層にボーリング孔を穿ちこれよりガス を抽出し，坑外に誇導することを考え,1943年Mansfeld 炭破に試みて成功した。これが新なるガス誘導の始め である。これがルール炭田よりザール，北仏，心゙ルギ ーイギリスに伝わり急速に普及しつつあるもので， わが国でも一昨年以来一部炭矷で寒施し始めている。 つぎに一昨年炭矿保安調査団の一員として視察した 下記西欧 5 炭砸の実状を基礎として述べる。 